\title{
How Did the Housing and Labor Market Crisis Affect Young Adults' Living Arrangements?
}

\author{
William H. Rogers ${ }^{1}$ \\ Anne Winkler ${ }^{2}$ \\ UMSL Department of Economics Working Paper \#1005
}

October 2014

\author{
Department of Economics \\ 408 SSB \\ University of Missouri - St. Louis \\ 1 University Blvd \\ St. Louis, MO 63121 \\ https://www.umsl.edu/econ/
}

1 University of Missouri-St. Louis

2 University of Missouri-St. Louis, Department of Economics and IZA Email: awinkler@umsl.edu 
IZA DP No. 8568

How Did the Housing and Labor Market Crises Affect Young Adults' Living Arrangements?

William H. Rogers

Anne E. Winkler

October 2014 


\title{
How Did the Housing and Labor Market Crises Affect Young Adults' Living Arrangements?
}

\author{
William H. Rogers \\ University of Missouri, St. Louis \\ Anne E. Winkler \\ University of Missouri, St. Louis \\ and IZA
}

Discussion Paper No. 8568

October 2014

IZA
P.O. Box 7240
53072 Bonn
Germany

\author{
Phone: +49-228-3894-0 \\ Fax: +49-228-3894-180 \\ E-mail: iza@iza.org
}

\begin{abstract}
Any opinions expressed here are those of the author(s) and not those of IZA. Research published in this series may include views on policy, but the institute itself takes no institutional policy positions. The IZA research network is committed to the IZA Guiding Principles of Research Integrity.

The Institute for the Study of Labor (IZA) in Bonn is a local and virtual international research center and a place of communication between science, politics and business. IZA is an independent nonprofit organization supported by Deutsche Post Foundation. The center is associated with the University of Bonn and offers a stimulating research environment through its international network, workshops and conferences, data service, project support, research visits and doctoral program. IZA engages in (i) original and internationally competitive research in all fields of labor economics, (ii) development of policy concepts, and (iii) dissemination of research results and concepts to the interested public.
\end{abstract}

IZA Discussion Papers often represent preliminary work and are circulated to encourage discussion. Citation of such a paper should account for its provisional character. A revised version may be available directly from the author. 
IZA Discussion Paper No. 8568

October 2014

\section{ABSTRACT \\ How Did the Housing and Labor Market Crises Affect Young Adults' Living Arrangements?*}

The housing and labor market crises of the late 2000s left few families and individuals unscathed. In the wake of these events, evidence points to more "doubling-up" of families in the same household. To what extent have these crises affected individuals' decisions to live independently? What differentiates this study from others is the careful attention paid to the role of housing market conditions - as measured by MSA-level housing prices, rents, and foreclosure rates - on this decision. The empirical analysis is conducted by appending data on area-level conditions for 85 of the largest MSAs in the United States to individual-level data from the ACS PUMS on living arrangements of young adults ages 22 to 34 living in these MSAs. The analysis spans the period 2005 (pre-crisis) through 2011. Within this time period, all MSAs experienced a rise in housing prices, a peak, and then a decline. Regarding the area-level variables, we find a robust statistically significant effect for rent only. Our broader conclusion is that it is individual-level factors, not area-level conditions that largely lie behind young adults' living arrangement decisions.

JEL Classification: J12, R23

Keywords: $\quad$ living arrangements, labor market, housing market, foreclosures

Corresponding author:

Anne E. Winkler

Department of Economics

University of Missouri, St. Louis

1 University Blvd.

St. Louis, MO 63121

USA

E-mail: awinkler@umsl.edu

\footnotetext{
* The authors gratefully acknowledge research funding from the University of Missouri Research Board.
} 


\section{Introduction}

The housing and labor market crises of the late 2000s left few families and individuals unscathed. ${ }^{1}$ In the wake of these events, evidence points to more "doubling-up" of families in the same household (Mykyta and Macartney, 2011; Elliott, Young, and Dye, 2011; Winkler \& Rogers, 2013) and the return of grown children to their parents' homes as well as their slower exit (Pew Organization, 2010 and 2013). ${ }^{2}$ While some recent research (Mykyta, 2012; Painter and $\mathrm{Yu}, 2013$ ) has started to investigate the effect of area-level labor market and housing conditions on individual-level living arrangements during the recent crises, the analyses have not paid sufficient attention to differences across Metropolitan Areas (MSAs) in terms of timing and severity. For instance, consider the situation in Las Vegas versus Dallas. The housing market collapsed in Las Vegas in 2006 while housing prices fell only slightly in Dallas beginning in 2008. At the national level, the housing market peaked in early 2007.

This study makes at least three contributions. First, in looking at young adults' living arrangements, we more fully characterize local area housing market conditions during the Great Recession than prior work: we examine MSA-level rents, housing prices, and foreclosure rates. Second, we use information on the timing of the housing market decline in each MSA to more clearly illuminate how living arrangements changed, and the reasons for this change, before and after and the housing peak. Finally, given the large data set at hand, we estimate models separately by minority status/gender and by age.

\footnotetext{
${ }^{1}$ For further discussion on the crises in the housing and labor markets during the Great Recession, see Ellen and Dastrup (2012).

${ }^{2}$ Even before the crises of the late 2000s, demographers noted the increasing rate of return (and delayed departure) of young adults from their parents' homes (Settersten and Ray, 2010; and Sironi and Furstenberg, 2012).
} 
The empirical analysis is conducted by appending data on housing and labor market conditions for 85 of the largest MSAs in the United States to individual-level data on living arrangements of young adults ages 22 to 34 living in these MSAs. The analysis spans the period 2005 (pre-crisis, and the first year that ACS data are available) through 2011. Within this time period, all MSAs examined experienced a rise in housing prices, a peak, and then a decline, albeit at different points in time. The individual-level data, for which we have over 1 million records, are from the American Community Survey (ACS) PUMS. The advantage of the ACS PUMS is its sheer size, which permits analysis by narrower demographic group (not just age, but also by race/gender). The focus is on young adults, those ages 22 to 34, given that they have lesser human capital and so are likely to be more sensitive to prevailing economic conditions than their more established counterparts. Moreover, considerable media attention has focused on this demographic group. Area-level conditions are captured at the MSA-level. Data on unemployment rates, housing prices, and rents, are from government sources. Data on foreclosure rates are from CoreLogic, a proprietary source.

To briefly summarize our results, we only find a robust statistically significant role for area-level rent. We find this result for both the pre- and post-crisis periods. Our overall conclusion is that it is chiefly individual-level factors not area-level conditions that lie behind individual living arrangement decisions.

II. Context: National and MSA Trends in Housing and Labor Market Conditions from 20052011

Figure 1 provides information on national U.S. labor market and housing market conditions from 2005 through early 2011. Housing prices in the nation accelerated during the 
early to mid 2000s, reaching a peak in first quarter 2007 based on the FHFA "All Transactions" housing price index. ${ }^{3}$ From annual 2007 to 2010, for instance, national housing prices declined nearly $13 \%$ in the U.S. as a whole and the foreclosure rate, a measure of acute housing distress, rose from .87 to $3.26 \%$, a whopping $274 \%$ increase. ${ }^{4}$ Trends in U.S. employment and unemployment are mirror images and both show a downturn in the labor market by the end of 2007/early 2008. From annual 2007 to 2010 , the unemployment rate rose from 4.6 to $9.6 \%$, while employment fell by $5.6 \%$. The data also show that the start date of the Great Recession of December 2007, as determined by the National Bureau of Economic Research (NBER), virtually coincides with the start of the labor market downturn. As shown in Figure 1, the national situation from 2005 to 2011 can be described as four distinct periods: the pre-crisis period (prior to 2007), the housing-crisis only period ( $1^{\text {st }}$ quarter 2007-end of 2007), the housing-recession period (end of 2007-summer 2009) and the post-recession period (after summer 2009). Even as of third quarter 2014, the national unemployment rate still hovered at around 6\%. In terms of timing of the labor market and housing market crises, Figure 1 shows the well-known story for the United States: the start of the housing crisis, as defined by the fall in housing prices, was followed by the downturn in the labor market.

What is not well-recognized but important, both from the standpoint of fully understanding the impact of the Great Recession and in doing empirical work, is the considerable variation by MSA in the onset and severity of the labor market and housing market "crises."

\footnotetext{
${ }^{3}$ Case and Quigley (2010), who describe the boom as being of "historical proportions," provide a succinct discussion of the unique set of events that precipitated the boom and lead to the subsequent bust.

${ }^{4}$ These estimates are highly sensitive to start and end dates. For instance, if the change in housing prices is calculated from first quarter 2007 to first quarter 2011, the price decline is $16 \%$.
} 
Most prior attention has focused on the national picture or the most severely affected MSAs such as Las Vegas and Miami. Rogers and Winkler (2013) was the paper first to systematically identify the dramatic variation in the timing of the onset of the labor market and housing crises for a large number of MSAs (over 350). Figure 2 and Table 1 illustrate this variation for 4 MSAs: Dallas, Las Vegas, Miami, and New York. Housing prices peaked earliest in Las Vegas and New York, with Miami's peak occurring one year later. In contrast, Dallas barely registered a change. Across all 85 MSAs examined, 7 experienced a housing peak prior to 2007, 30 experienced a peak in 2007, 36 experienced a peak in 2008 and 11 experienced a peak after 2008.

Returning to the four illustrative MSAs, both Las Vegas and Miami experienced a dramatic post-peak fall in prices; from the respective peak in each MSA until 2011, prices fell $17 \%$ and $14 \%$ each year, on average. In contrast, the decline was far more modest at just $3.4 \%$ per year on average in New York. Of the four MSAs, Las Vegas experienced the sharpest rise in the unemployment rate, topping out at 14\% in 2010. Finally, Table 1 and Figure 2 point to the dramatic increases in foreclosure rates, with rates of $18 \%$ in Miami and $7.5 \%$ in Las Vegas as of 2011. ${ }^{5}$ These experiences have been well-documented in the media, with Miami receiving the dubious distinction of being labelled the "foreclosure capital" of the United States (Brannigan, 2013). The question investigated in this paper naturally follows: to what extent does the dramatic variation in housing prices, foreclosure rates, and unemployment rates across MSAs and over time explain variation in individuals' living arrangements?

\footnotetext{
${ }^{5}$ As discussed in the data section, foreclosure rates are calculated by CoreLogic as number of homes in foreclosure as a percent of homes with a first mortgage, akin to a default rate.
} 
III. Prior Literature on the Effect of Macroeconomic Conditions on Living Arrangements

The study of living arrangements, both regarding its trends and determinants, is quite extensive. ${ }^{6}$ An important subtopic in this literature is the relationship between macroeconomic conditions and living arrangements. Notably, the terminology varies somewhat across the social science disciplines—-household formation, living arrangements, doubling-up, co-residence—but the basic concept is essentially the same. Urban economists have had a long-standing interest in the effect of housing prices and rents on household formation (doubling-up) because household formation is a key factor in determining the homeownership rate. ${ }^{7}$ Labor economists, demographers, and sociologists have had particular interest in the determinants of living arrangements, especially as they pertain to implications for the well-being of children, young adults, and the elderly. Here we review the most related recent studies conducted following the Great Recession and the housing bust of the late 2000s as well as review a handful of the most closely related studies that predate these events.

A number of recent studies have sought to explicitly link changes in the housing market and/or labor market during the recent crisis to changes in household formation at the MSA level.

\footnotetext{
${ }^{6}$ Goldscheider and DaVanzo (1985) completed one of the earliest studies of the sociodemographic determinants of living arrangements. Among the most recent related studies, albeit not focused on macroeconomic conditions, Kahn et al. (2013) analyzed the past 40-year period and found that co-residence of young adults and their parents is now more often a consequence of the young adults' financial need rather than need of their parents. Also quite relevant is recent research by Billari and Liefbroer (2007) on the influence of societal and friends norms on home-leaving and research by Settersten and Ray (2010) and Sironi and Furstenberg (2012) on young adults' failure to launch" from their parents' homes.

${ }^{7}$ The "homeownership rate" is equal to the number of owner-occupied homes divided by the number of households. This rate is affected not only by changes among those living independently who change from renter to buyer (or vice versa) but also by changes in living independently versus doubling-up, which directly affects the denominator (number of households) and is the focus of this study. For a recent study see Haurin and Rosenthal (2007) and for earlier studies in this area see Borsch-Supan (1986) and Ermisch (1999).
} 
Dunne (2012) used MSA-level data on persons age 18-34 to investigate the correlation between household formation (e.g. headship rates and number of households) and labor market conditions and the correlation between household formation and housing prices. He found that doubling-up is associated to some extent with both weak housing and labor markets, but did not probe further. Painter (2012) used data on 80 MSAs from the American Community Survey (ACS) for 20052008 to examine changes in household headship, homeownership, and overcrowding within a dwelling for MSAs grouped by immigrant status. He found that headship rates and overcrowding rose while homeownership declined for all groups examined, though to differing extents. Kaplan (2012) used repeated cross-sections from the Current Population Survey for 1979 to 2010 to estimate state-level co-residence rates of individuals ages 16-24 (and 16-34) as a function of measures of labor market conditions (employment rate, average hours worked). $\mathrm{He}$ found that weak labor market conditions have a significant positive effect on co-residence with parents, a finding that was maintained even when housing prices were explicitly incorporated into the specification. ${ }^{8}$ Rogers and Winkler (2013) looked at the relationship between living arrangements and macroeconomic conditions for over 350 MSAs before and during the recent crises and identified only weak associations between changes in doubling-up and measures of these crises. ${ }^{9}$ While these various studies are informative, causality is generally difficult to discern.

\footnotetext{
${ }^{8}$ In the remainder of the paper, Kaplan (2012) goes on to model co-residence as a dynamic game between youth (young adults) and their parents. The paper hypothesizes and finds supporting evidence that co-residence with parents is a form of insurance against risk.

${ }^{9}$ In a somewhat more distantly related study, Dettling and Kearney (2011) looked at the impact of variations in MSA-level housing prices during the recent crisis on MSA-level fertility patterns.
} 
Another strand of research has used the same empirical approach as in this paper and looked at the effect of macroeconomic conditions at the state- and MSA-levels on living arrangements (e.g. headship) at the individual-level. A prime advantage of this approach is that the direction of causality clearly runs from macroeconomic events to individual-level decisions. The two most related papers, both which focused on living arrangements during the most recent crisis, are Mykyta (2012) and Painter and Yu (2013). Mykyta (2012) estimated a model of doubling-up of young adults ages 18-34 using microdata from the Current Population Survey for the years 2007 and 2010 in an effort to capture the pre- and post-crisis periods. Macro variables included measures of lagged housing prices (measured as the state housing price index) and lagged county unemployment rates, but notably, no measure of rent. Among the results, Mykyta found that higher unemployment and higher housing prices discourage living independently.

The focus of the paper by Painter and Yu (2013) is entirely different — it centers on differences in headship and homeownership outcomes of immigrants versus non-immigrants by type of immigrant community (established gateways, emerging gateways, and metro) — but there are notable similarities in methodology. These authors used microdata from the American Community Survey (the same data used here) on all adults ages 18-64 for the years 2006 and 2009 in 80 MSAs. ${ }^{10}$ The MSA-level measures used were the unemployment rate, log of median rent, $\log$ of housing prices at the $25^{\text {th }}$ percentile, and change in mortgage delinquency rates. In their headship analyses for the full sample of all adults ages 18-64, they found that mortgage delinquency and unemployment rates had no effect and that "the most important housing market characteristic in predicting headship rates is rent in the metropolitan area." They also estimated

${ }^{10}$ One difficulty in fully comparing the multivariate micro-level analysis of Painter and Yu (2013) with the study at hand is that they do not precisely define headship. 
separate models for 2006 and 2009 to see if effects differed pre- and post-crisis. In this analysis they identified "small changes in the sensitivity of headship rates to rents [only]."

Cohen (2014) used a used a similar methodology, but looked at the effects of area-level factors on the probability of divorce. Specifically, he appended state-level data on unemployment rates and foreclosure filings to individual-level data on divorce from the ACS PUMS for 2008 to 2011. Notably, after including state fixed effects, he did not find that area-level variables had a significant relationship with divorce. However, some additional analyses suggested that findings may be sensitive to level of educational attainment.

Another relevant recent paper was completed by Molloy and Shan (2011). One important methodological difference is that they looked at the effect of an own foreclosure experience on household formation, rather than area-level foreclosures as analyzed here. They used data on individuals from the FRBNY/Equifax Consumer Credit Panel for the period 1999-2010. Their overall conclusion is that a personal foreclosure experience did not have a notable effect on household composition or, in fact, any of the outcomes investigated.

Several additional papers provide valuable insights, though they do not focus on the period of the late 2000s. ${ }^{11}$ Yelowitz (2007) analyzed living arrangements of young adults using Census data for decennial years 1970 through 2000. Macro variables included housing prices (a median measure adjusted by the FHFA housing price index), HUD's Fair Market Rent, and the state unemployment rate (as the MSA-level one was not available for the full period). He found a significant role for area-level housing prices and state unemployment rates in reducing independent living, but no effect of rent. In other work, Curtis et al. (2013) looked

${ }^{11}$ Other earlier research includes Haurin, Hendershott, and Kim (1993), Zhu and Liu (1996), and Winkler (1992). These studies all found that higher rents, as measured using HUD's Fair Market Rent, have a negative significant effect on living independently. 
homelessness, what is arguably the most dire living arrangement, during the early 2000s. These authors merged individual-level data from the Fragile Families Survey on homelessness with area-level housing and labor market data. To capture housing market conditions, they focused on two variables that reflect the lower end of the housing market: HUD Fair Market Rents and a measure of housing subsidies. In some specifications, they also included city-level unemployment rates. They found that having a child with a health shock has a significant positive effect on homelessness, an effect that is compounded for those living in cities with higher rents.

Finally, Lee and Painter (2013) used PSID data on young adults from 1975-2009 (covering 6 recessions, though the analysis did not focus on the unique attributes of the most recent recession) to examine the decision of young adults initially living with their parents to leave home and either live independently as an owner or as a renter. They included macro variables at the state-level: GDP growth rate, the unemployment rate, real wage, median gross rent, and measures of median house value. ${ }^{12}$ The authors found that it was higher unemployment rates as well as own unemployment that significantly (both in terms of statistical significance and magnitude) reduced exits from the parental household.

The takeaways of this literature review are two-fold. First, only a limited number of studies to date on living arrangements have focused on the most recent period of the Great Recession and housing crisis, and those that have, have not fully characterized the crisis. Second, findings regarding the impact of area-level housing and labor market conditions on individualliving arrangements appear to vary considerably from study to study.

\footnotetext{
${ }^{12}$ For housing measures, they also examined HUD's Fair Market Rent (FMR) and FHFA's Housing Price Index.
} 


\section{Contributions of this Study}

This study builds upon the current research in several ways. First, in looking at the decision to live independently versus double-up by young adults, we pay very careful attention to what happened in local area labor and housing markets. Except for those at the very bottom of the income distribution (see analysis on homelessness by Curtis et al. 2013), a full description of housing conditions necessitates the inclusion of information on both rents and housing prices. As noted, Mykyta (2012) excluded rent. Also, given the dramatic rise in foreclosures over the period studied (see Figure 1), we further include a measure of foreclosure rates. Foreclosures reflect what was happening in submarkets where extensive subprime lending occurred. ${ }^{13}$

Second, we do much a more careful job than prior work in defining the pre- and postcrisis periods. The method undertaken by Mykyta (2012) and Painter and Yu (2013) was to assume that 2006 (or 2007) was the pre-period and a subsequent year (2009 or 2011) was a post year, and then draw comparisons. However, this approach ignores the fact that the onset of the crises differed by MSA, as highlighted in Figure 2. In this study we first identify the housing peak for each MSA and then, in one of the model specifications, examine the relationship between housing and labor market conditions and living independently pre- and post-peak.

Finally, given the large data set at hand, we are able estimate the relationship between macroeconomic conditions and living independently for narrower demographic groups. For instance, considerable evidence indicates that the age of home-leaving has risen and so the

\footnotetext{
${ }^{13}$ Painter and Yu (2013) included area-level mortgage delinquency rates, which convey essentially the same information. However, as noted in the literature review, while there are similarities in variable specification, their paper's focus is on decisions of immigrants versus USborn individuals in different types of immigrant communities, not on the decision of young adults.
} 
decisions of very young adults and older young adults are likely to be quite different (Settersten and Ray, 2010; and Sironi and Furstenberg, 2012). Further, given that we have over 1 million individual records, we are able to estimate models by minority status/gender, thereby capturing the interaction between race and gender (Brown and Misra, 2003).

V. Data and Methods

In the empirical work, we estimate logit models to investigate the impact of MSA-level housing and labor market variables on the individual-level decision to live independently versus double-up. As mentioned earlier, an advantage of having data at two levels is that we can better pin down the direction of causality. Specifically we merge data on housing and labor market conditions for 85 of the largest MSAs with data on individuals living in these MSAs from the Public Use Microdata Files (PUMS) underlying the American Community Survey (ACS) for the period 2005-2011. ${ }^{14}$ The descriptive statistics presented in Table 3 describe trends in all variables, both individual-level and MSA-level, for this full period. However, the sample used in the analysis is for years 2006-2011, as shown in Table 4. The estimation sample is narrower because the MSA-level variables are included in the logit models with a one-year lag. So, for instance, the decision to live independently in 2006 is modelled as a function of prevailing MSAlevel housing prices in 2005, the first year ACS data are available.

\footnotetext{
14 There are 367 total MSAs (Metropolitan, Micropolitan, and Metro Divisions) in the FHFA housing price index series. Here we focus on 85 of the largest MSAs. In Yelowitz (2007), he used data on around 60 MSAs.
} 


\section{Measures of Housing and Labor Market Conditions}

Labor market conditions are measured using BLS data on MSA unemployment rates. For exposition purposes only, Figure 1 also provides comparison data on employment rates. At the aggregate level, these measures are effectively mirrors of each other.

Housing market conditions are captured using three area-level measures: housing prices, rents, and foreclosure rates. Housing prices are measured by multiplying a FHFA single-family housing price index (index has a value of $1=$ in 2005) by the median housing price in $2005 .{ }^{15}$ This measure, similar to the one constructed by Yelowitz (2007), captures both differences in the level of cost of homes across areas and changes in the price of housing over time. In constructing this measure, median gross housing price data are from the ACS. The housing price index used is FHFA's "Purchase-Only" Housing Price Index. Its better known counterpart is the "All Transactions" Index (reported in Table 1). Both indexes utilize data collected from Fannie Mae and Freddie Mac. The advantage of using the "Purchase-Only" Index is that this index includes actual sales price data only; the "All Transactions" Index" further includes information on appraisals which may provide misleading information in turbulent times.

MSA-level rents are measured using median gross rent from the ACS. Often, rents and housing prices are thought to move in the same direction. However, during the crisis, especially, it has been speculated that rents may have moved differently from housing prices. Specifically, as people moved out of owned homes and into renting, this may have put upward pressure on

\footnotetext{
${ }^{15}$ Another well-known constant price housing index is the Case-Schiller Housing Price Index, which is calculated for 20 MSAs. The FHFA covers more MSAs and like Case-Schiller, it is constructed using a repeat-sales method to capture constant quality. Specifically, sales observations are not included unless the housing unit has been sold at least twice in the data series. The advantage of this methodology is that it effectively controls for housing quality (housing prices are not just going up because bigger homes are being built).
} 
rents, leading to a co-existence of falling home prices and rising rents in some areas (Ellen and Dastrup, 2012). However, the current evidence is not conclusive on this point. For instance, Ambrose et al. (2012) identify an overall decline in rents. ${ }^{16}$ In this study, both are included since they reflect alternative costs of an independent living arrangement.

To fully characterize area housing markets, especially during the late 2000s, area-level foreclosure rates are also included. Foreclosures haven been especially acute in housing submarkets with large numbers of subprime loans. Foreclosures are measured using proprietary data obtained from CoreLogic for the period 2005 to 2011. CoreLogic and Realtytrac are the two sources that have been most heavily cited/used for foreclosure data during the recent housing crisis. CoreLogic provides information on 85 percent of first mortgages, which is regarded as excellent coverage. ${ }^{17}$ In the Corelogic data, a foreclosure is defined as a situation where ownership of the property is in the process of changing hands. The foreclosure rate is calculated as foreclosures per number of first mortgages, akin to a default rate.

The three measures of the housing market and the unemployment are correlated to some extent, as would be expected. The correlation between rent and housing prices is .77. Also relatively high is the correlation between the foreclosure rate and the unemployment rate, at $.58 .^{18}$ All variables are retained in the main analyses because the objective is to capture, as much as possible, the key features of the housing market. For instance, in isolating the impact of

\footnotetext{
${ }^{16}$ Unlike the housing price index, no government source presently provides a constant quality rental price index; Ambrose et al. (2012) are working on such a measure.

${ }^{17}$ For a comparison of CoreLogic with other well-known sources of foreclosure data, including RealtyTrac, see Mortgage Banker's Association (2008). The two surveys have slightly different methods of counting foreclosures and foreclosure rates.

${ }^{18}$ In contrast, the correlation between the unemployment and rent is just .15 and the correlation between the unemployment rate and housing price is -.18.
} 
housing prices, it is important to hold constant employment conditions. Similarly, such an analysis permits identification of the effect of an increase in housing prices, holding rents constant. However, for purposes of sensitivity testing, the models are re-estimated with one or more variables excluded to see if multicollinearity is driving the results obtained and to compare the results with the findings of other studies cited earlier. Also, additional models are estimated including "change" variables (e.g. \% change in housing price) along with levels as a further specification check.

Table 3 provides aggregate data on all 85 MSAs, for the period 2005-2011. In the sample examined, the average unemployment rate stood at a low of $4.5 \%$ in 2006 and a high of $9.7 \%$ in 2010. The median area housing price declined from a high of $\$ 281,300$ in 2006 to $\$ 220,000$ in 2010. Finally, foreclosure rates (foreclosures per first mortgage) rose from virtually zero to $3.9 \%$ over the full period. Changes in in these variables across the 4 illustrative MSAs, as described in Table 1 and Figure 2 are even more striking.

\section{ACS Data}

Data on individual living arrangements are from the ACS PUMS. A prime advantage of the ACS PUMS is that it is the largest household survey in the U.S. with information on 3 million addresses. In all analyses, group quarters (e.g. dorms and institutional settings) are omitted as a household type. ${ }^{19}$ The focus is on young adults, defined as ages 22 to 34 , given their greater potential sensitivity to economic conditions than their more established counterparts.

${ }^{19}$ One notable difference between the ACS and Current Population Survey (CPS) is the treatment of college students living in dorms. In the ACS, a college student currently living in a dorm is counted as "living in Group Quarters" (so not included as a household member) while this same college student would be included among the current household members in the CPS. See Kromer and Howard (2011). 
Young adults are identified as living in one of two arrangements: Independent or Other.

Similar to the categorization scheme of Mykyta (2012), a living arrangement is defined as Independent if the young adult: $:^{20}$

1) heads his/her own household and lives alone and/or lives with their children < age 18 (and the household does not include a subfamily or nonrelative(s));

2) is a married householder or spouse of householder (and the household does not include a subfamily or nonrelative(s));

3) is an unmarried partner who is the householder or the unmarried partner of the householder (and the household does not include a subfamily).

Other arrangements include young adults who live with their parents, those who live with a roommate, those who live with siblings, etc. ${ }^{21}$

Table 3 shows trends in independent living for young adults over the period 2005 to 2011 (all 85 MSAs combined and weighted). In 2011, 56.3\% of young adults ages 22-34 lived independently, down from $66.1 \%$ in 2005 . As would be expected, living independently is much more common among older young adults, as shown in Table 4 (these are the same data but averaged over 2006 to 2011, which are the years used in the logit analysis). The decline in living independently over the period, as well as the patterns by age, are consistent with earlier research

${ }^{20}$ One difference should be noted. In her analysis using the CPS, Mykyta (2012) classifies those who are enrolled in school as "dependent," a choice that may be necessitated by the fact, per an earlier footnote, students in dorms are included as household members in the CPS. In this study, we exclude those in dorms (group quarters). Further, independent versus dependent living arrangement status is not made contingent on college enrollment (or not). Nonetheless, since the living arrangement decision may be associated with current enrollment status, the estimated regressions include this variable as a control.

${ }^{21}$ The precise definition of Other is as follows: lives with relative (parent, sibling, grandparent or other relative); and/or lives with nonrelative (housemate/roommate, roomer/boarder, in-law, or other non-relative). 
by Mykyta (2012), Mykyta and Macartney (2011), and Elliot, Young, and Dye (2011), to name just a few. ${ }^{22}$

In addition to MSA-level variables, the analysis includes standard individual-level sociodemographic characteristics identified in the prior literature. All models include age and one specification also stratifies the analysis by "younger" and "older" young adults. Educational attainment is captured with a set of dummy variables that reflect completion level: less than high school (which includes the GED), high school only, some college, and four or more years (the reference group). Marital status is captured by a set of dummy variables as well: married, never married (the reference group), and other marital status. Minority status is defined as nonHispanic white. Finally, we include measures of current college enrollment (enrolled or not enrolled) and employment status (employed or not employed). At the individual level, not employed is more meaningful than unemployed because the BLS's definition of unemployment is contingent upon search in the last four weeks (otherwise the individual is classified as "not in the labor force"). Table 3 provides means for each variable for years 2005 to 2011. As would be expected given worsening economic conditions, the percent of young adults ages 22-34 not employed increased from $7.5 \% 2005$ to $11.6 \%$ in 2011.

Given the nature of the ACS data - a repeated cross-section panel of individuals-we should note that the data are subject to the same potential critiques as prior work by Yelowitz (2007), Mykyta (2012), and Painter and Yu (2013). Principally, these data do not provide information on parental income or wealth, variables which are available and have been utilized in analyses of home leaving conducted using longitudinal data by Yu and Painter (2013), among

\footnotetext{
${ }^{22}$ The levels differ somewhat given differences in the age range of young adults analyzed and differences in the definition of an independent living arrangement (e.g. the treatment of young adults enrolled in school, as discussed in an earlier footnote).
} 
others. We recognize this limitation, but as with all analysis, there are always tradeoffs; as noted an advantage of the ACS PUMS over longitudinal data sets is its sheer size.

There has also been some recent discussion about the role of college debt in reducing the affordability of establishing an independent living arrangement (Brown et al. 2014; Dettling and Hsu, 2014). Again, the ACS does not collect such information. While this factor may play a role, at least two caveats should be kept in mind. First, the distribution of student debt held by borrowers is highly skewed. As reported by Brown et al. (2014) using Federal Reserve Bank of New York data, only $3.7 \%$ of all student borrowers had debt exceeding $\$ 100,000$, while $40 \%$ of borrowers had debt of less than $\$ 10,000$, and $70 \%$ had debt of less than $\$ 25,000$ (per Figure 4 in their paper). Second, Akers and Chingos (2014) argue that the issue is not just debt alone, but the ratio of debt to income. They find that the ratio of debt to income did not increase all that much over the period examined here (and, in fact, declined for some measures). To address this point, at least superficially here, we re-estimated the living arrangement specifications for those who have no potential college debt (that is, those who are neither enrolled nor ever completed any college) as compared to those who might have college debt.

\section{Merging of ACS PUMS and MSA-Level Housing and Labor Market Measures}

The ACS identifies geographic areas in terms of Public Use Metropolitan Areas (PUMAs). A PUMA is defined to be a geographic area of 100,000 persons. (There had previously also been the concept of SUPERPUMA, areas of 400,000+ persons, but this was discontinued). The PUMAs in a state sum to the state population. PUMAs do not cross state boundaries. A critical part of the analysis was to match PUMAs to MSAs (the latter, which do cross state bounds). This was accomplished using MABEL/Geocorr2K, a utility provided by the Missouri Data Center (MDC). Specifically, for all years (2005-2011), geographic area definitions 
for the ACS PUMAS based on 2000 geography were matched to MSA boundaries, as defined in 2008.

\section{Empirical Methods}

In the empirical work, we estimate the decision to live independently for young adults ages 22-34, where live independently is set equal to 1 if the individual lives independently, as defined earlier, or 0 otherwise. Given the dichotomous nature of the dependent variable, logit estimation is used. For ease of interpretation, marginal effects and associated standard errors (clustered by MSA) are reported. Each outcome is estimated as a function of the same set of individual-level covariates (the vector $\mathbf{X}$, described in the earlier section) plus time dummies and 84 MSA dummies. All regression models are estimated for the period 2006 to 2011. Data from 2005 are utilized to create the lagged MSA variables and the "change" variables discussed below.

Model 1 includes one-year lagged measures of the MSA-level unemployment rate (Urate), median housing price (Hprice), foreclosure rate (Foreclrate), and median gross rent (Rent) along with individual-level control variables:

$$
\begin{aligned}
& \text { Live Indep }_{\mathrm{ijt}}=\mathrm{B}_{\mathrm{o}}+\mathrm{B}_{1} \text { Urate }_{\mathrm{jt}-1}+\mathrm{B}_{2} \text { Rent }_{\mathrm{jt}-1}+\mathrm{B}_{3} \text { Hprice }_{\mathrm{jt}-1}+\mathrm{B}_{4} \text { Foreclrate }_{\mathrm{jt}-1} \\
& +\mathbf{B} \mathbf{X}_{\mathrm{ijt}}+\mathrm{e}_{\mathrm{ijt}}
\end{aligned}
$$

The MSA-level unemployment rate reflects overall labor market conditions. It can be thought of an indicator of uncertainty of individuals' longer-term job prospects; even if an individual is currently employed, his/her decisions may be affected by what is happening more generally to those living near them. Higher area rents and higher area housing prices, both which reflect aspects of the affordability of an independent living arrangement, are expected to depress living independently. It is important to include both measures in light of other research, cited 
earlier, that rents and housing prices may not have moved in sync during the Great Recession. Finally turning to area-level foreclosures, the effect on living independently is ambiguous. Higher rates reflect an "opportunity" to afford to live independently for those who are not currently homeowners. However, they may also contribute to an atmosphere of uncertainty and instability, and make individuals wary about living independently.

Model 2 further includes changes in the macro-level variables: These changes are measured as point changes for variables initially defined as rates (Urate and Foreclrate), and percent changes for variables initially defined as levels (Hprice and Rent):

$$
\begin{aligned}
& \text { Live Indep }_{\mathrm{jt}}=\mathrm{B}_{\mathrm{o}}+\mathrm{B}_{1} \text { Urate }_{\mathrm{jt}-1}+\mathrm{B}_{2} \text { Rent }_{\mathrm{jt}-1}+\mathrm{B}_{3} \text { Hprice }_{\mathrm{jt}-1+\mathrm{B}_{4} \text { Foreclrate }_{\mathrm{jt}-1}} \\
& +\mathrm{B}_{5} \Delta \text { urate }_{\mathrm{jt}}+\mathrm{B}_{6} \% \Delta \text { Rent }_{\mathrm{t}} \mathrm{B}_{7} \% \Delta \text { Hprice }_{\mathrm{jt}}+\mathrm{B}_{8} \Delta \text { Foreclrate }_{\mathrm{jt}} \\
& +\mathbf{B X}_{\mathrm{ijt}}+\mathrm{e}_{\mathrm{ijt}}
\end{aligned}
$$

Rising rents, as well as higher rent levels, are expected to discourage living independently because this arrangement is less affordable. In the case of rising housing prices, the effect is ambiguous. This is because housing demand has both a consumption and investment motive (Henderson and Ionnides, 1984). On the one hand, as in the case of rent, rising housing prices reduce affordability (and thus living independently), but on the other hand rising housing prices may signal future appreciation and, in turn, an investment opportunity. So, if the investment motive dominates, rising housing prices could actually spur independent living as a homeowner. Finally, rising foreclosures, like a higher level of foreclosures, are expected to have an ambiguous effect on living independently; a rising rate may reflect an "opportunity," all else equal, to acquire a property at lower cost, but it may also be an indicator of an uncertain economic environment. 
We further estimate additional model specifications that allow the effects of the variables in Model 2-both macro-level and individual-level covariates - to vary across the pre- and posthousing peak periods for each MSA. The pre-peak period is defined as 2006 through the year at which housing prices reached their peak within each MSA; the post-peak period is defined as the years following the peak. This specification allows for the possibility, for instance, that labor market uncertainty may have had an even greater negative effect on living independently in the face of the housing market collapse. Also, in the post-peak period, we expect there to be less of an investment motive associated with falling housing prices.

The time dummies control for changes in national conditions (e.g. changes in mortgage rates) over the period of study. The MSA dummies permit us to hold other MSA level factors (apart from housing and labor market conditions) constant. This approach means that we are effectively identifying the relationship between housing prices (or other macro variables) and living independently by exploiting variation within MSAs over time. As shown in Table 1 and Figure 2, this empirical approach is well-justified given the tremendous variation in housing prices, rents, foreclosure rates, and unemployment rates for each MSA over the period examined.

\section{Empirical Findings}

Tables 5-8 present logit regression results of the probability of living independently. Each table reports marginal effects and standard errors clustered by MSA. Models 1 and 2 in Table 5 match the specifications in the text; Model 1 has the MSA-level variables measured as lagged levels and Model 2 further includes these variables as changes from the prior year. This section focuses on the findings regarding these macro-level variables, although it should be noted that the findings for individual-level control variables have signs consistent with expectations 
(and are all statistically significant). ${ }^{23}$ What is most striking in Models 1 and 2 of Table 5 is that the only MSA-level variable that has a statistically significant effect on living arrangements is rent, entered as a level (Rent) and as percentage change (\% $\%$ Rent $)$. While statistically significant, rent's role is not arguably "economically" significant. Results from Model 2 indicate that a $\$ 100$ increase in rent (around $10 \%$ of the mean) reduces the probability of living independently by just .01 percentage points and a 1 point increase in the rate of increase in rent has a -.001 point impact. $^{24}$

One might argue that perhaps the lack of significant findings for the MSA-level variables is a consequence of the fact that Models 1 and 2 of Table 5 include three correlated (to some degree) measures of housing market variables. However, as shown in Table 6, even if rent is excluded (though theoretically it is a relevant variable), housing prices are not found to be statistically significant. In fact, across a variety of alternative specifications of the MSA-level variables, no measure is found to have a statistically significant relationship, apart from rent.

In Tables 7 and 8, we report results by age group (ages 22-27 versus 28-34) and by racegender. In Model 1 of Table 7, "age 28-34" is entered as a dummy and is interacted with each covariate in the model. For ease of presentation, column 1 of Model 1 reports the main effect and column two reports the interaction term (“age $28-34$ "*each covariate). Thus, the marginal effects in column 1 report results for those ages 22-27 and the sum of columns 1 and 2 provide effects for those ages 28-34. In this specification, Rent and $\% \Delta$ Rent are found to have a statistically significant negative effect on living independently. Notably, these effects do not differ

\footnotetext{
${ }^{23}$ Statistical significance of individual covariates is to be expected given the sample size of over 1 million records.

${ }^{24}$ The level variable for Rent is measured in $\$ 1,000$ s in estimating the model for exposition purposes. However, it is not realistic to think about a $\$ 1,000$ increase in rent since the mean of rent is also around $\$ 1,000$. For this reason, the text discusses a $\$ 100$ increase.
} 
significantly by age group (the marginal effects on the interaction terms are insignificant). The foreclosure rate is found to have a negative significant effect for older young adults, but notably this is the only specification estimated where foreclosures are found to have a significant impact. Model 2 of Table 7 allows the effect of the covariates - both individual and area-wiseto differ depending on whether housing prices were rising (pre-peak) or had begun to fall (postpeak) in each MSA. ${ }^{25}$ This specification is in contrast to earlier research which made the simplifying assumption that the pre- and post-housing peak periods were the same for all MSAs. In this specification, we find a negative significant effect of $\% \Delta$ Rent (but no effect of rent, measured at its level), both pre- and post-peak. However, from a quantitative standpoint, the effect is weaker in the post-peak period. Interestingly, consistent with the "investment" story posited earlier, rising housing prices pre-peak increased living independently; in other words, rising prices may have encouraged living independently (through the channel of home ownership) on the basis of gains in equity. However, this is the only specification where this result is found. ${ }^{26}$

25 "Post-peak" is defined as once housing prices fell, so pre-peak includes the peak year. This model also included a dummy for post-peak; however, there is not a meaningful interpretation for the post-peak intercept alone.

${ }^{26}$ In results not reported here, we also estimated a specification to investigate the effect of arealevel variables on those who had potential college debt (were enrolled in college or had completed at least a year of college) versus those who had no potential college debt (neither enrolled in college nor ever completed any college). We found a significant negative effect on Rent and $\% \Delta$ Rent for both groups (as found in other estimated models), but no significant difference in the relative effects. For those without potential college debt only, we also found that rising housing prices significantly reduced living independently, consistent with the affordability story. 
Table 8 provides results for all race-gender groups pooled together and then separately by race-gender. ${ }^{27}$ Again, area-level rent is found to have a statistically significant negative effect on living independently for all groups (for minority males, the effect operates exclusively through $\% \Delta$ Rent, not rent measured at its level). These models also indicate a significant negative effect of area-wide unemployment rates (what we view as a measure of labor market uncertainty), albeit only for non-Hispanic white men and women.

To sum up the findings, while some specifications provide evidence of effects of arealevel factors including changes in housing prices, the foreclosure rate, and the unemployment rate, it is rent that is almost always statistically significant, measured as a level or as percentage change. This finding regarding rent makes intuitive sense since we are looking at young adults who are less established, in terms of career and asset accumulation.

\section{Conclusion}

This study investigated the effect of MSA-level housing characteristics — rents, housing prices, and foreclosure rates - as well as MSA-level unemployment rates on the decision to live independently versus double-up for over 1 million young adults living in over 80 MSAs for the period 2005 (pre-crisis) to 2011. Individual-level data were drawn from the ACS PUMS. The analysis exploited considerable variation within MSAs over the study period. To date, findings have been "all over the board" regarding the effects of MSA-level factors on the individual-level decision to live independently. In this study we identified rent as the most robust factor in terms

\footnotetext{
${ }^{27}$ In the interaction-term specifications presented in Table 7, the individual-level and MSA-level covariates vary by group, but not the time or fixed effects. In these models, each estimated separately, all factors may differ across groups. We took this approach in Table 8 largely for purposes of exposition.
} 
of statistical significance. However, despite the robust significant finding, its effect is economically small; a $\$ 100$ increase in rent (around 10\% of the mean) reduces the probability of living independently by just a little under .01 percentage points. In some models, we also identified a role for unemployment rates, foreclosure rates, and changes in housing prices, but these findings did not hold up across specifications. Our larger conclusion based on the results obtained here is that it is individual-level determinants, not broader area-level ones, which are driving young adults' living arrangement decisions.

The findings obtained in this paper are, in fact, broadly consistent with at least three studies that have focused on the period of the Great Recession: Painter and Yu (2013), Cohen (2014), and Molloy and Shan (2011). In their study of headship decisions of immigrants and non-immigrants, Painter and Yu (2013) used a similar methodology and largely identified a role for rent only, as found here. Cohen (2014) found little evidence that state-level economic conditions affected divorce in his main analysis, though exploratory work suggested that the impact of economic conditions might vary by educational attainment. Finally, in the case of Molloy and Shan (2011), they used a different methodology (individual level data on foreclosures) and found little effect of foreclosures on household composition or other outcomes.

We would argue that the analysis undertaken here contributes to the extant knowledge on young adults' living arrangements because we used a data set that spanned the period before and after the recent crisis, paid particular attention to the measurement of the MSA-level variables, and more precisely identified the differential effects of area-level factors pre- and post-crisis. Further the size of the ACS PUMS ensured considerable variation within and across MSAs, which was important for identifying (or not) effects of area-level variables on individual decisions. However, as with all empirical studies, this approach and this study, in particular, 
have limitations. In using repeated cross-sections, we do not have information on parental resources and wealth, both variables which are generally included in longitudinal data sets. Also valuable would be information on parental (or other family) transfers to support young adults' independent living arrangements. Finally, these data cannot fully resolve the empirical question of the extent to which college debt has truly "set back" household formation of young adults, as reported in media outlets. 


\section{References}

Ambrose, B.W., N.E. Coulson, and J. Yoshida. (2012). The repeat rent index. Working Paper. Pennsylvania State University. http://www.econ.psu.edu/ ecoulson/repeat_rent_3.pdf

Akers, Beth and M. M. Chingo. 2014. Is a student loan crisis on the horizon? Washington, DC: Brown Center on Edu ation Policy, Brookings Institution. http://www.brookings.edu/research/reports/2014/06/24-student-loan-crisis-akers-chingos

Billari, F.C. and A.C. Liefbroer. (2007). Should I stay or should I go? The impact of age norms on leaving home. Demography, 44(1), 181-198.

Bitler, M. and Hoynes, H. (2013). The more things change, the more they stay the same: The safety net, living arrangements, and poverty in the great recession. NBER Working Paper 19449.

Borsch-Supan, A. (1986). Household formation, housing prices, and public policy impacts. Journal of Public Economics, 30, 145-164.

Brown, M. and S. Caldwell. 2013. Young student loan borrowers retreat from housing and auto markets. Liberty Street Economics (April 17, 2013).

Browne, I. and J. Misra. 2003. "The intersection of gender and race in the labor market. Annual Review of Sociology 29, 487-513.

Brown, M., A. Haughwout, D. Lee, J. Scally and W. van der Klaauw (2014). Measuring student debt and its performance. Staff Paper of Federal Reserve Bank of New York, April 2014 (Number 668).

Cohen, P. N. (2014). Recession and divorce in the United States: 2007-2011. Population Research and Policy Review (forthcoming).

Dettling, L. J. and M.S. Kearney. (2011). House prices and birth rates: The impact of the real estate market on the decision to have a baby, NBER Working Paper No. 17485.

Dettling, L.J. and J. Hsu. (2014). Returning to the nest: debt and parental co-residence among young adults. Paper Presented at Population Association of America Meetings.

Dunne, T. (2012). Household formation and the great recession. Economic Commentary (Federal Reserve Bank of Cleveland).

Ellen, I. G. \& S. Dastrup. (2012). Housing and the great recession. NY: Russell Sage Foundation and the Stanford Center on Poverty and Inequality.

Elliott, D.B., R. Young, and J. L. Dye. (2011). Variation in the formation of complex family households during recession. U.S. Census Bureau SEHSD Working Paper No. 2011-4. 
Ermisch, J. F. (1999). Prices, parents, and young people's household formation. Journal of Urban Economics, 45, 47-71.

Furstenberg, F. F. (2010). On a new schedule: Transitions to adulthood and family change. Future of Children, 20, 67-87.

Goldscheider F. and Julie DaVanzo. (1985). Living arrangements and the transition to adulthood. Demography 22(4), 545-563.

Haurin, D.R., P.H. Hendershott, and D. Kim. (1993).The impact of real rents and wages on household formation. Review of Economics and Statistics, 75, 284-293.

Haurin, D. R. \& Rosenthal, S. (2008). The influence of household formation on homeownership rates across time and race. Real Estate Economics, 35(4), 411-450.

Henderson, J.V. and Y. Ioannides. (1983). A model of housing tenure choice. American Economic Review, 73 (1), 98-113.

Kahn, J.R., F.G. Goldscheider. (2013). Growing parental economic power in parent-adult child houseohlds: Co-residence and financial dependency in the United States, 1960-2010. Demography, 50, 1449-1475.

Kaplan, G.W. (2012). Moving back home: insurance against labor market risk. Journal of Political Economy, 120(3), 446-512.

Kromer, B.K. and D.J. Howard. (2011). "Comparison of ACS and CPS data on employment status. " US Census Bureau: Social, Economic, and Housing Statistics Division. SEHSD Working Paper, 2011-31.

Lee, K. and G. Painter. (2013). What happens to household formation in a recession? Journal of Urban Economics 76, 93-109.

Molloy, R. and H. Shan. (2011). The post-foreclosure experience of U.S. households. Finance and Economics Discussion Series 2011-32. Washington, DC: Board of Governors of the Federal Reserve.

Mortgage Bankers Association. (2008). Sources of foreclosure data. MBA Research DataNotes. Retrieved from http://www.mortgagebankers.org/default.htm

Mykyta L. and S. Macartney. 2012. Sharing a household: household composition and economic well-being: 2007-2010. Current Population Report p60-242. Washington, DC: U.S. Census Bureau.

Mykyta, L. and S. Macartney. 2011. The effects of recession on household composition: Doubling Up" and Economic Well-Being. U.S. Census Bureau SEHSD Working Paper No. 2011-4. http://www.census.gov/hhes/www/poverty/publications/papers.html 
Mykyta L. (2012). Economic downturns and the failure to launch: the living arrangements of young adults in the U.S., 1995-2011. U.S. Census Bureau. SEHSD Working Paper No. 2012-24.

Painter, G. and Z. Yu. (2013). Caught in the housing bubble: Immigrants' housing outcomes in traditional gateways and newly emerging destinations. Urban Studies (online 23 July 2013): 781809.

Painter, G. (2012). What happens to household formation in a recession? Institute for Housing America.

Pew Organization. (2010). The return of the multi-generational family household. Retrieved from http://pewsocialtrends.org/files/2010/10/752-multi-generational-families.pdf

Pew Organization. (2013). A rising share of young adults live in their parents' home. (August 1, 2013).

Rogers, W. H. and A. E. Winkler. 2013. The relationship between the housing \& labor market crises and doubling-up: An MSA-level analysis, 2005-2010," Monthly Labor Review (August):132.

Setterson, R.A. and B. Ray. (2010). What's going on with young people today? The long and twisting path to adulthood. Future of Children, 20, 19-41.

Sironi, M. and F.F. Furstenberg. (2012). Trends in the economic independence of young adults in the United States: 1973-2007. Population and Development Review, 38 (4).

U.S. Census Bureau website. http://www.census.gov/hhes/families/about/ (accessed 15 January 2013).

Winkler, A. E. (1992). The impact of housing costs on the living arrangements of single mothers," Journal of Urban Economics, 32(3), 388-403.

Yelowitz, A. (2007). Young adults leaving the nest: The role of the cost of living. In S. Danziger $\&$ C. E. Rouse (Eds.), The price of independence: The economics of early adulthood (pp.170-206). New York: Russell Sage.

Zhu, X. D. \& X. Liu (2006). The effects of housing push factors and rent expectations on household formation of young adults. Journal of Real Estate Research, 28(2), 149-166. 
Figure 1. Trends in the U.S. Labor Market and Housing Market

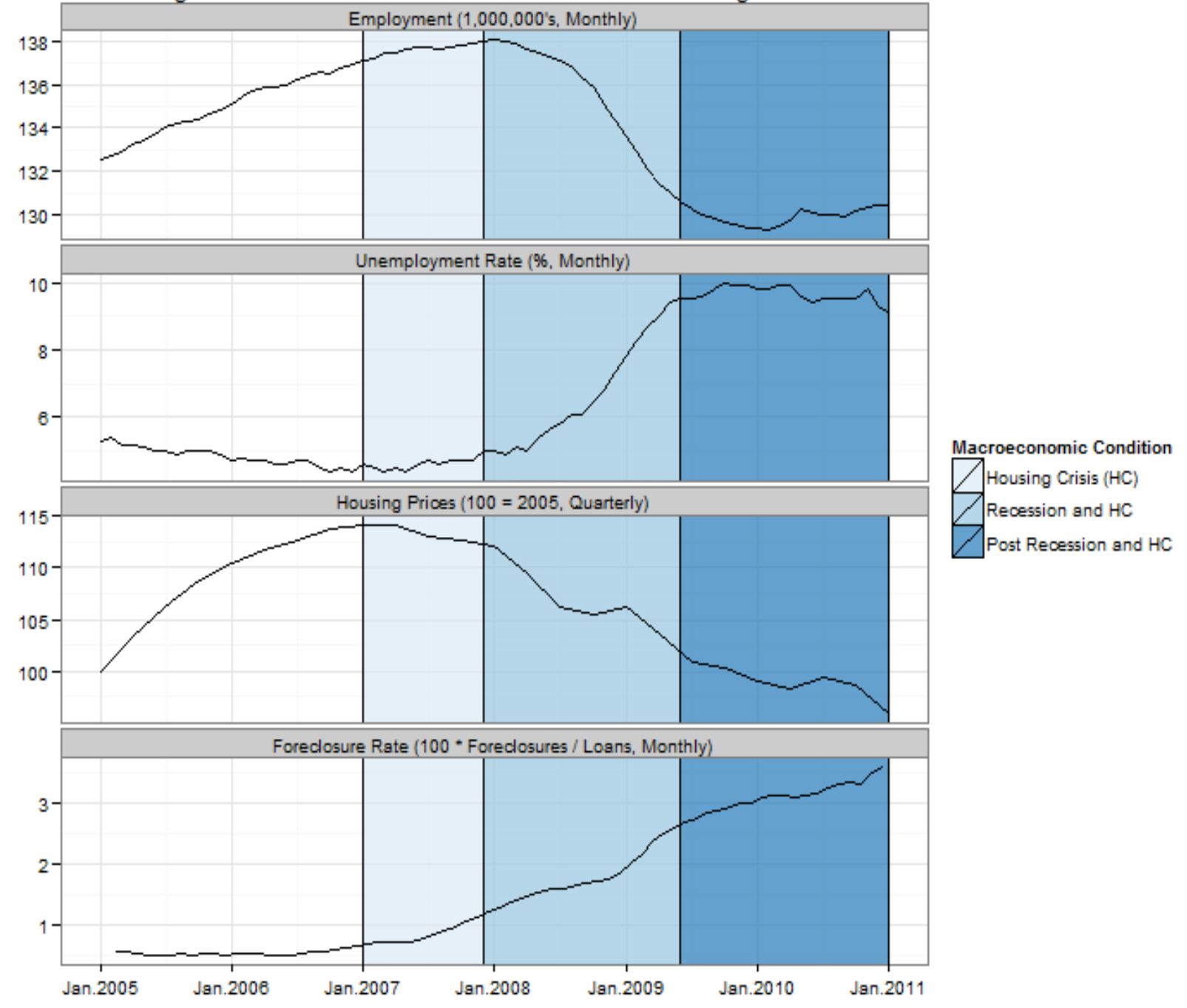

Sources: Housing prices are from the FHFA, All Transactions Index; Foreclosure Rates are from Core Logic; Employment and unemployment rate data are from the Bureau of Labor Statistics. 
Figure 2. Illustration of Variation in Housing and Labor Market Conditions for 4 MSAs, 2005-2011.

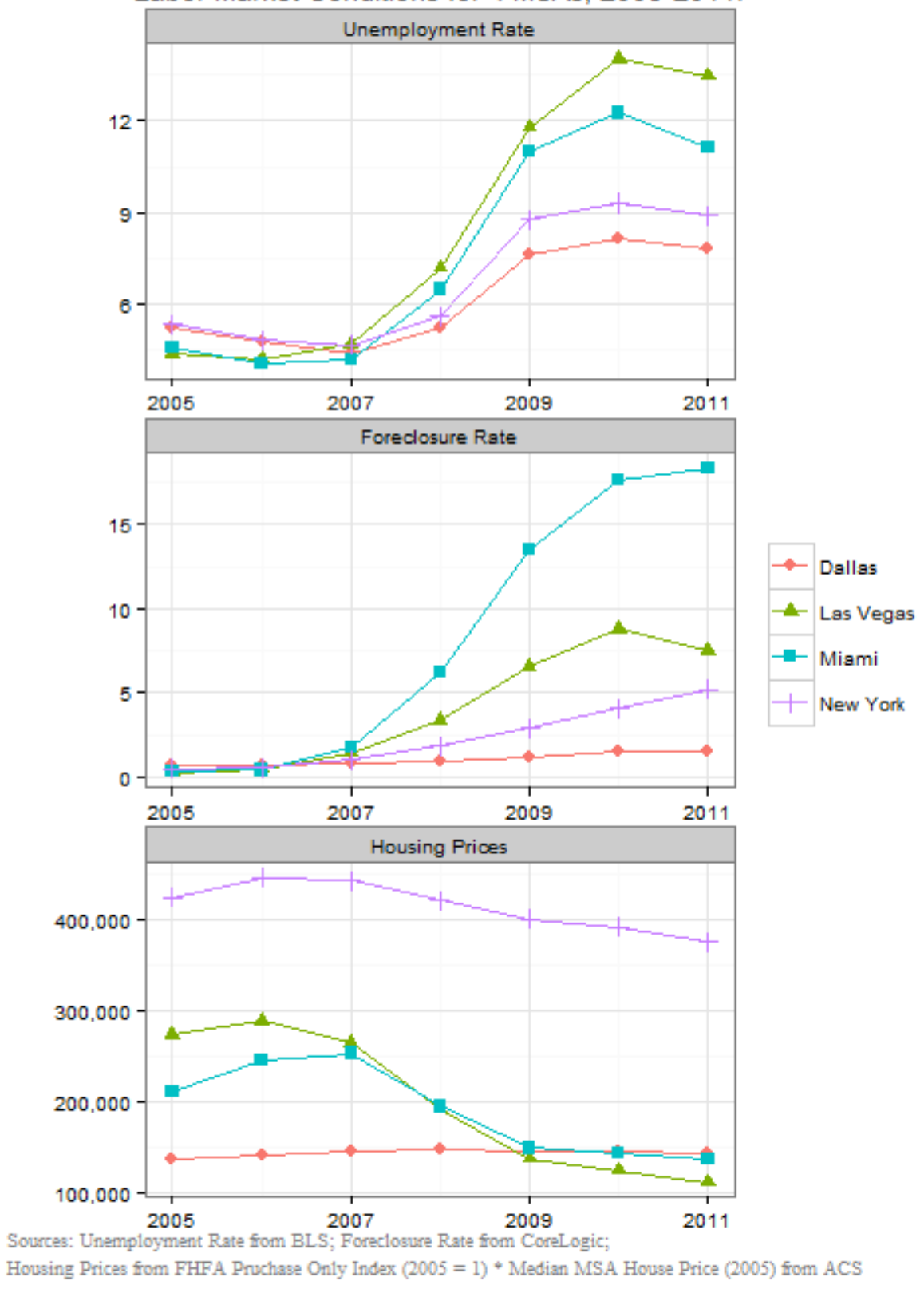


Table 1. Variation in Housing and Labor Market Conditions for 4 MSAs, 2005 - 2011

\begin{tabular}{|c|c|c|c|c|c|c|c|}
\hline & 2005 & 2006 & 2007 & 2008 & 2009 & 2010 & 2011 \\
\hline \multicolumn{8}{|l|}{ Dallas } \\
\hline Unemployment Rate (\%) & 5.26 & 4.81 & 4.38 & 5.25 & 7.62 & 8.15 & 7.80 \\
\hline Foreclosure Rate (\%) & 0.65 & 0.66 & 0.74 & 0.91 & 1.20 & 1.46 & 1.53 \\
\hline Housing Prices & $\$ 136,985$ & $\$ 142,300$ & $\$ 146,662$ & $\$ 147,466$ & $\$ 146,671$ & $\$ 146,033$ & $\$ 143,943$ \\
\hline \multicolumn{8}{|l|}{ Las Vegas } \\
\hline Unemployment Rate (\%) & 4.40 & 4.22 & 4.72 & 7.20 & 11.78 & 14.02 & 13.47 \\
\hline Foreclosure Rate (\%) & 0.23 & 0.44 & 1.42 & 3.35 & 6.56 & 8.79 & 7.49 \\
\hline Housing Prices & $\$ 274,207$ & $\$ 289,300$ & $\$ 265,683$ & $\$ 192,432$ & $\$ 137,711$ & $\$ 124,884$ & $\$ 112,333$ \\
\hline \multicolumn{8}{|l|}{ Miami } \\
\hline Unemployment Rate (\%) & 4.61 & 4.08 & 4.20 & 6.50 & 10.99 & 12.26 & 11.12 \\
\hline Foreclosure Rate (\%) & 0.34 & 0.40 & 1.73 & 6.25 & 13.47 & 17.64 & 18.34 \\
\hline Housing Prices & $\$ 211,450$ & $\$ 246,500$ & $\$ 253,781$ & $\$ 195,367$ & $\$ 149,589$ & $\$ 144,172$ & $\$ 138,009$ \\
\hline \multicolumn{8}{|l|}{ New York } \\
\hline Unemployment Rate (\%) & 5.35 & 4.84 & 4.66 & 5.63 & 8.78 & 9.31 & 8.91 \\
\hline Foreclosure Rate (\%) & 0.46 & 0.52 & 0.99 & 1.82 & 2.86 & 4.09 & 5.16 \\
\hline Housing Prices & $\$ 425,462$ & $\$ 447,400$ & $\$ 443,577$ & $\$ 422,107$ & $\$ 401,503$ & $\$ 392,510$ & $\$ 376,069$ \\
\hline
\end{tabular}

Sources: Unemployment Rate from Bureau of Labour Statistics; Foreclosure Rate (foreclosures/first mortgage) from CoreLogic. Housing Prices from FHFA Purchase Only Index, calculated as Price Index (2005=1) * Median MSA House Price (2005) from American Community Survey. 
Table 2. Definitions and Sources of MSA-Level Variables Used in Analyses Presented in Tables 3-8.

Variable

$\begin{array}{ll}\text { Housing Price } & \text { Hprice } \\ \text { Rent } & \text { Rent } \\ \text { Unemployment Rate } & \text { Urate } \\ \text { Foreclosure Rate } & \text { Foreclrate }\end{array}$

Variable Measurement

Constructed as FHFA Purchase-Price Index $(2005=1)^{*}$ Median Housing Price in 2005 (in \$100K)

Median Gross Rent (in $\$ 1,000)$

Civilian Unemployment Rate, age 16+ (as a proportion)

Foreclosures per Number of Loans (as a proportion)
Source Information

Housing Price Index from FHFA; Median House Price from ACS Tables

ACS Tables

Bureau of Labor Statistics

CoreLogic

Notes: $\Delta$ Urate, $\Delta$ Foreclosure are calculated as year-to-year point change in the respective variable. $\% \Delta H P r i c e$ and $\% \Delta$ rent are calculated as as year-to-year percentage change in the respective variable. 
Table 3. Descriptive Statistics for all Individuals (ages 22-34) in all 84 MSAs, by Year, 2005-2011

\begin{tabular}{|c|c|c|c|c|c|c|c|}
\hline & 2005 & 2006 & 2007 & 2008 & 2009 & 2010 & 2011 \\
\hline Female & 0.549 & 0.544 & 0.539 & 0.540 & 0.551 & 0.546 & 0.550 \\
\hline Minority & 0.464 & 0.470 & 0.467 & 0.468 & 0.459 & 0.473 & 0.475 \\
\hline Some College Completed & 0.305 & 0.302 & 0.303 & 0.327 & 0.324 & 0.324 & 0.328 \\
\hline High School Only Completed & 0.248 & 0.256 & 0.255 & 0.225 & 0.221 & 0.220 & 0.220 \\
\hline Not Employed & 0.075 & 0.068 & 0.069 & 0.069 & 0.109 & 0.118 & 0.116 \\
\hline Not Enrolled in College & 0.853 & 0.855 & 0.855 & 0.849 & 0.845 & 0.838 & 0.835 \\
\hline Married & 0.423 & 0.394 & 0.385 & 0.375 & 0.363 & 0.357 & 0.344 \\
\hline Not Married, Not Single & 0.074 & 0.074 & 0.071 & 0.070 & 0.068 & 0.065 & 0.065 \\
\hline Urate & 0.050 & 0.045 & 0.045 & 0.060 & 0.091 & 0.097 & 0.091 \\
\hline Foreclrate & 0.005 & 0.005 & 0.009 & 0.017 & 0.029 & 0.036 & 0.039 \\
\hline
\end{tabular}

Notes: These calculations are based on 1.8+ millions records from the ACS PUMS for 84 of the largest MSAs.

2006-2011 analysis.

Omitted category for educational completion is at least four years of college; omitted category for marital status is never-married.

Minority refers to non-Hispanic white. MSA-level variables are defined in Table 2. 
Table 4. Descriptive Statistics of MSA-Level and Individual-Level Covariates used in Logit Estimations, by Age, 2006-2011

\begin{tabular}{|c|c|c|c|c|c|c|c|c|c|c|c|c|}
\hline & \multicolumn{4}{|c|}{ Ages 22-34 (full sample) } & \multicolumn{4}{|c|}{ Ages 22-27 } & \multicolumn{4}{|c|}{ Ages 28-34 } \\
\hline & $\begin{array}{l}\text { Unweighted } \\
\text { Mean }\end{array}$ & $\begin{array}{l}\text { Weighted } \\
\text { Mean }\end{array}$ & Min & Max & $\begin{array}{c}\text { UnweightedM } \\
\text { ean }\end{array}$ & $\begin{array}{l}\text { Weighted } \\
\text { Mean }\end{array}$ & Min & Max & $\begin{array}{c}\text { Unweighted } \\
\text { Mean }\end{array}$ & $\begin{array}{l}\text { Weighted } \\
\text { Mean }\end{array}$ & Min & Max \\
\hline Live Independently & 0.637 & 0.587 & 0.000 & 1.000 & 0.467 & 0.424 & 0.000 & 1.000 & 0.773 & 0.723 & 0.000 & 1.000 \\
\hline Female & 0.483 & 0.464 & 0.000 & 1.000 & 0.492 & 0.473 & 0.000 & 1.000 & 0.475 & 0.457 & 0.000 & 1.000 \\
\hline Ages 28-34 & 0.554 & 0.545 & 0.000 & 1.000 & NA & NA & NA & NA & NA & NA & NA & NA \\
\hline Minority & 0.420 & 0.469 & 0.000 & 1.000 & 0.419 & 0.462 & 0.000 & 1.000 & 0.421 & 0.474 & 0.000 & 1.000 \\
\hline Some College Completed & 0.314 & 0.318 & 0.000 & 1.000 & 0.343 & 0.348 & 0.000 & 1.000 & 0.290 & 0.294 & 0.000 & 1.000 \\
\hline High School Only Completed & 0.209 & 0.232 & 0.000 & 1.000 & 0.226 & 0.248 & 0.000 & 1.000 & 0.195 & 0.220 & 0.000 & 1.000 \\
\hline Less than HS Completed & 0.091 & 0.108 & 0.000 & 1.000 & 0.091 & 0.105 & 0.000 & 1.000 & 0.092 & 0.111 & 0.000 & 1.000 \\
\hline Not Employed & 0.088 & 0.092 & 0.000 & 1.000 & 0.106 & 0.109 & 0.000 & 1.000 & 0.073 & 0.078 & 0.000 & 1.000 \\
\hline Not Enrolled in College & 0.838 & 0.846 & 0.000 & 1.000 & 0.768 & 0.781 & 0.000 & 1.000 & 0.894 & 0.900 & 0.000 & 1.000 \\
\hline Married & 0.410 & 0.369 & 0.000 & 1.000 & 0.245 & 0.220 & 0.000 & 1.000 & 0.542 & 0.494 & 0.000 & 1.000 \\
\hline Not Married, Not Single & 0.063 & 0.069 & 0.000 & 1.000 & 0.034 & 0.037 & 0.000 & 1.000 & 0.086 & 0.095 & 0.000 & 1.000 \\
\hline Urate $_{t-1}$ & 0.065 & 0.065 & 0.024 & 0.172 & 0.065 & 0.065 & 0.024 & 0.172 & 0.065 & 0.065 & 0.024 & 0.172 \\
\hline$\Delta$ Urate & 0.007 & 0.007 & -0.021 & 0.053 & 0.007 & 0.007 & -0.021 & 0.053 & 0.007 & 0.007 & -0.021 & 0.053 \\
\hline Foreclrate $_{t-1}$ & 0.017 & 0.017 & 0.000 & 0.176 & 0.017 & 0.017 & 0.000 & 0.176 & 0.017 & 0.017 & 0.000 & 0.176 \\
\hline$\Delta$ foreclrate & 0.006 & 0.006 & -0.014 & 0.072 & 0.006 & 0.006 & -0.014 & 0.072 & 0.006 & 0.006 & -0.014 & 0.072 \\
\hline Hprice $_{\mathrm{t}-1}$ (in $\$ 100,000 \mathrm{~s}$ ) & 2.525 & 2.512 & 0.830 & 0.072 & 2.522 & 2.498 & 0.830 & 7.791 & 2.528 & 2.523 & 0.830 & 7.791 \\
\hline$\% \Delta$ Hprice & -0.038 & -0.038 & -0.430 & 0.209 & -0.038 & -0.038 & -0.430 & 0.209 & -0.038 & -0.038 & -0.430 & 0.209 \\
\hline Rent $_{\mathrm{t}-1}$ (in $\$ 1,000 \mathrm{~s}$ ) & 0.921 & 0.919 & 0.568 & 1.442 & 0.921 & 0.917 & 0.568 & 1.442 & 0.922 & 0.921 & 0.568 & 1.442 \\
\hline$\% \Delta$ Rent & 0.030 & 0.029 & -0.063 & 0.217 & 0.030 & 0.030 & -0.063 & 0.217 & 0.030 & 0.029 & -0.063 & 0.217 \\
\hline
\end{tabular}

Notes: These calculations are based on 1.8+ millions records from the ACS PUMS for 84 of the largest MSAs. 2005 data were used to create the "change" variables for the 2006-2011 analysis.

Omitted category for educational completion is at least four years of college; omitted category for marital status is never-married. Minority refers to non-Hispanic white. MSA-level variables are defined in Table 2. 
Table 5. Marginal Effects Calculated from Logit Regressions Estimating the Probability of Living Independently

\section{Model 1}

Age 28-34

Female

Minority

Some College Completed

High School Only Completed

Less Than HS Completed

Not Employed

Not Enrolled in College

Married

Other Marital Status

$\Delta$ Urate

Foreclrate $_{\mathrm{t}-1}$

$\Delta$ Foreclrate

Hprice $_{\mathrm{t}-1}$ (in $\$ 100,000$ s)

$\% \Delta$ Hprice

Rent $_{\mathrm{t}-1}$ (in \$1,000s)

$\% \Delta$ Rent

$0.203^{* * *}$

(0.004)

0.079

(0.002)

$-0.043^{* * *}$

$(0.007)$

$-0.062$

(0.003)

$-0.149$

$(0.004)^{* * *}$

$-0.175$

(0.009)

$-0.116$

(0.004)

0.083

(0.003)

0.399

(0.006)

$0.098^{* *}$

(0.002)

$-0.056$

(0.152)

0.023

(0.204)

0.006

(0.026)

0.023

(0.053)

$-0.001$

$-0.001$

(0.003)

(0.004)

0.015

(0.020)

$-0.119$

(0.043)

$-0.142^{* * *}$

(0.044)

$-585050$

1183226

1183226

Observations

Notes: Logit models estimated over years 2006 to 2011 using data from 84 of the largest MSAs. All models include time and MSA fixed effects. Marginal effects are reported. Standard errors (in parentheses) are clustered by MSA. $* * * p<0.01, * * p<0.05,{ }^{*} p<0.1$ 
Table 6. Sensitivity Testing of Model 1 Presented in Table 5.

\begin{tabular}{|c|c|c|c|c|c|c|}
\hline & $\begin{array}{l}\text { Model 1, } \\
\text { Table } 5\end{array}$ & $\begin{array}{l}\text { Exclude } \\
\text { Rent }\end{array}$ & $\begin{array}{l}\text { Exclude } \\
\text { Hprice }\end{array}$ & $\begin{array}{l}\text { Exclude } \\
\text { Foreclrate }\end{array}$ & $\begin{array}{l}\text { Exclude } \\
\text { Hprice, } \\
\text { Foreclrate } \\
\end{array}$ & $\begin{array}{l}\text { Exclude } \\
\text { Rent, } \\
\text { Foreclrate } \\
\end{array}$ \\
\hline Urate $_{t-1}$ & $\begin{array}{l}-0.056 \\
(0.152)\end{array}$ & $\begin{array}{l}0.038 \\
(.168)\end{array}$ & $\begin{array}{l}-0.043 \\
(0.145)\end{array}$ & $\begin{array}{l}-0.019 \\
(0.146)\end{array}$ & $\begin{array}{l}0.007 \\
(0.130)\end{array}$ & $\begin{array}{l}0.053 \\
(0.158)\end{array}$ \\
\hline Foreclrate $_{t-1}$ & $\begin{array}{l}0.017 \\
(0.028)\end{array}$ & $\begin{array}{l}0.008 \\
(0.030)\end{array}$ & $\begin{array}{l}0.018 \\
(0.027)\end{array}$ & & & \\
\hline Hprice $_{\mathrm{t}-1}$ (in $\left.\$ 100,000 \mathrm{~s}\right)$ & $\begin{array}{l}-0.001 \\
(0.003)\end{array}$ & $\begin{array}{l}0.002 \\
(0.004)\end{array}$ & & $\begin{array}{l}-0.001 \\
(0.003)\end{array}$ & & $\begin{array}{l}0.002 \\
(0.003)\end{array}$ \\
\hline Rent $_{t-1}$ (in $\$ 1,000 s$ ) & $\begin{array}{l}-0.076^{* *} \\
(0.034)\end{array}$ & & $\begin{array}{l}-0.074^{* *} \\
(0.032)\end{array}$ & $\begin{array}{l}-0.072^{* *} \\
(0.034)\end{array}$ & $\begin{array}{l}-0.069^{* *} \\
(0.032)\end{array}$ & \\
\hline Log Likelihood & -585061 & -585069 & -585062 & -585062 & -585063 & -585069 \\
\hline Observations & 1183226 & 1183226 & 1183226 & 1183226 & 1183226 & 1183226 \\
\hline
\end{tabular}

Notes: Logit models estimated over years 2006 to 2011 using data from 84 of the largest MSAs. All models include same covariates as in Table 5 plus time and MSA fixed effects. Marginal effects are reported. Standard errors (in parentheses) are clustered by MSA.

$* * * p<0.01,{ }^{* *} p<0.05, * p<0.1$ 
Table 7. Marginal Effects Calculated from Logit Regressions Estimating the Probability of Living Independently: Models with Post Peak and Age Interaction

Model 1

Model 2

\begin{tabular}{|c|c|c|c|c|}
\hline & \multicolumn{2}{|c|}{$\begin{array}{l}\text { Model With Age } \\
\text { Interaction }\end{array}$} & \multicolumn{2}{|c|}{$\begin{array}{l}\text { Model With Post-Peak } \\
\text { Interaction }\end{array}$} \\
\hline & Variable & $\begin{array}{l}\text { Variable * } \\
\text { age } 28-34\end{array}$ & Variable & $\begin{array}{l}\text { Variable } * \\
\text { Post Peak }\end{array}$ \\
\hline Age 28-34 & $\begin{array}{l}0.244^{* * *} \\
(0.021)\end{array}$ & & $\begin{array}{l}.197^{* * *} \\
(0.005)\end{array}$ & $\begin{array}{l}0.008^{* *} \\
(0.004)\end{array}$ \\
\hline Female & $\begin{array}{l}0.081^{* * *} \\
(0.002)\end{array}$ & $\begin{array}{l}-0.003 \\
(0.003)\end{array}$ & $\begin{array}{l}0.080^{* * *} \\
(0.003)\end{array}$ & $\begin{array}{l}-0.002 \\
(0.003)\end{array}$ \\
\hline Minority & $\begin{array}{l}-0.031^{* * *} \\
(0.008)\end{array}$ & $\begin{array}{l}-0.025^{* * *} \\
(0.004)_{* * *}\end{array}$ & $\begin{array}{l}-0.043^{* * *} \\
(0.007)\end{array}$ & $\begin{array}{l}0.000 \\
(0.005)\end{array}$ \\
\hline Some College Completed & $\begin{array}{l}-0.047^{* * *} \\
(0.003)\end{array}$ & $\begin{array}{l}-0.032^{* * *} \\
(0.004)\end{array}$ & $\begin{array}{l}-0.065^{* * *} \\
(0.004)_{* * *}\end{array}$ & $\begin{array}{l}0.004 \\
(0.003)\end{array}$ \\
\hline High School Only Completed & $\begin{array}{l}-0.118^{* * *} \\
(0.004)^{* * *}\end{array}$ & $\begin{array}{l}-0.062^{* * *} \\
(0.005)^{* * *}\end{array}$ & $\begin{array}{l}-0.150^{* * *} \\
(0.005)_{* * *}\end{array}$ & $\begin{array}{l}0.000 \\
(0.004)\end{array}$ \\
\hline Less Than HS Completed & $\begin{array}{l}-0.126^{* * *} \\
(0.007)\end{array}$ & $\begin{array}{l}-0.083^{* * *} \\
(0.008)\end{array}$ & $\begin{array}{l}-0.200^{* * *} \\
(0.010)_{* * *}\end{array}$ & $\begin{array}{l}0.028^{* * *} \\
(0.005)\end{array}$ \\
\hline Not Employed & $\begin{array}{l}-0.115^{* * *} \\
(0.004)\end{array}$ & $\begin{array}{l}-0.004 \\
(0.003)\end{array}$ & $\begin{array}{l}-0.124^{* * *} \\
(0.006)\end{array}$ & $\begin{array}{l}0.008^{*} \\
(0.004)\end{array}$ \\
\hline Not Enrolled in College & $\begin{array}{l}0.097^{* * *} \\
(0.003)\end{array}$ & $\begin{array}{l}-0.044^{* * *} \\
(0.004)\end{array}$ & $\begin{array}{l}0.086^{* * *} \\
(0.004)\end{array}$ & $\begin{array}{l}-0.004 \\
(0.003)\end{array}$ \\
\hline Married & $\begin{array}{l}0.411^{* * *} \\
(0.005)\end{array}$ & $\begin{array}{l}-0.034^{* * *} \\
(0.005)^{* * *}\end{array}$ & $\begin{array}{l}0.417^{* * *} \\
(0.006)^{* * *}\end{array}$ & $\begin{array}{l}-0.033^{* *} \\
(0.007)\end{array}$ \\
\hline Other Marital Status & $\begin{array}{l}0.127^{* * *} \\
(0.004)\end{array}$ & $\begin{array}{l}-0.058^{* * *} \\
(0.006)\end{array}$ & $\begin{array}{l}0.103^{* * *} \\
(0.003)\end{array}$ & $\begin{array}{l}-0.009^{*} \\
(0.005)\end{array}$ \\
\hline Urate $_{\mathrm{t}-1}$ & $\begin{array}{l}-0.226 \\
(0.171)\end{array}$ & $\begin{array}{l}0.157 \\
(0.099)\end{array}$ & $\begin{array}{l}0.264 \\
(0.307)\end{array}$ & $\begin{array}{l}-0.337 \\
(0.235)\end{array}$ \\
\hline$\Delta$ Urate & $\begin{array}{l}0.081 \\
(0.214)\end{array}$ & $\begin{array}{l}-0.118 \\
(0.105)\end{array}$ & $\begin{array}{l}0.158 \\
(0.311)\end{array}$ & $\begin{array}{l}-0.049 \\
(0.259)\end{array}$ \\
\hline Foreclrate $_{\mathrm{t}-1}$ & $\begin{array}{l}0.072 \\
(0.044)\end{array}$ & $\begin{array}{l}-0.131^{* *} \\
(0.061)\end{array}$ & $\begin{array}{l}0.669 \\
(0.810)\end{array}$ & $\begin{array}{l}-0.660 \\
(0.814)\end{array}$ \\
\hline$\Delta$ Foreclrate & $\begin{array}{l}0.084 \\
(0.067)\end{array}$ & $\begin{array}{l}-0.117 \\
(0.081)\end{array}$ & $\begin{array}{l}0.463 \\
(0.482)\end{array}$ & $\begin{array}{l}-0.454 \\
(0.484)\end{array}$ \\
\hline Hprice $_{\mathrm{t}-1}$ (in $\$ 100,000 \mathrm{~s}$ ) & $\begin{array}{l}0.000 \\
(0.004)\end{array}$ & $\begin{array}{l}0.000 \\
(0.004)\end{array}$ & $\begin{array}{l}-0.001 \\
(0.005)\end{array}$ & $\begin{array}{l}0.002 \\
(0.002)\end{array}$ \\
\hline$\% \Delta$ Hprice & $\begin{array}{l}0.025 \\
(0.028)\end{array}$ & $\begin{array}{l}-0.023 \\
(0.034)\end{array}$ & $\begin{array}{l}0.118^{*} \\
(0.067)\end{array}$ & $\begin{array}{l}-0.112 \\
(0.070)\end{array}$ \\
\hline Rent $_{\mathrm{t}-1}$ (in \$1,000s) & $\begin{array}{l}-0.154^{* * *} \\
(0.050)\end{array}$ & $\begin{array}{l}0.055 \\
(0.037)\end{array}$ & $\begin{array}{l}-0.080 \\
(0.054)\end{array}$ & $\begin{array}{l}-0.032 \\
(0.025)\end{array}$ \\
\hline$\% \Delta$ Rent & $\begin{array}{l}-0.145^{* *} \\
(0.058)\end{array}$ & $\begin{array}{l}-0.001 \\
(0.071)\end{array}$ & $\begin{array}{l}-0.273^{* * *} \\
(0.077)\end{array}$ & $\begin{array}{l}0.175^{* *} \\
(0.078)\end{array}$ \\
\hline Post-Peak & & & $\begin{array}{l}0.042^{*} \\
(0.025)\end{array}$ & \\
\hline $\begin{array}{l}\text { Log-Likelihood } \\
\text { Observations }\end{array}$ & & $\begin{array}{l}83930 \\
83226\end{array}$ & & $\begin{array}{l}4944 \\
3226\end{array}$ \\
\hline
\end{tabular}

Notes: Logit models estimated over years 2006 to 2011 using data from 84 of the largest MSAs. All models include time and MSA fixed effects. Marginal effects are reported. Standard errors (in parentheses) are clustered by MSA. In the age interaction model, each covariate is entered individually and then multiplied by age28-34. In the postpeak interaction model, each covariate is entered individually and then interacted with the dummy postpeak.

$* * * p<0.01, * * p<0.05, * p<0.1$ 
Table 8. Marginal Effects Calculated from Logit Regressions Estimating the Probability of Living Independently

\begin{tabular}{|c|c|c|c|c|c|}
\hline & $\begin{array}{l}\text { Pooled } \\
\text { Groups }\end{array}$ & $\begin{array}{l}\text { White Non- } \\
\text { Hispanic } \\
\text { Male }\end{array}$ & $\begin{array}{l}\text { White Non- } \\
\text { Hispanic } \\
\text { Female }\end{array}$ & $\begin{array}{l}\text { Minority } \\
\text { Male }\end{array}$ & $\begin{array}{l}\text { Minority } \\
\text { Female }\end{array}$ \\
\hline Age 28-34 & $\begin{array}{l}0.203^{* * *} \\
(0.004)\end{array}$ & $\begin{array}{l}0.188^{* * *} \\
(0.004)\end{array}$ & $\begin{array}{l}0.156^{* * *} \\
(0.004)\end{array}$ & $\begin{array}{l}0.218^{* * *} \\
(0.004)\end{array}$ & $\begin{array}{l}0.216^{* * *} \\
(0.004)\end{array}$ \\
\hline Female & $\begin{array}{l}0.079^{* * *} \\
(0.002)^{* * *}\end{array}$ & & & & \\
\hline Minority & $\begin{array}{l}-0.043^{* * *} \\
(0.007)^{* * *}\end{array}$ & & & & \\
\hline Some College Completed & $\begin{array}{l}-0.062^{* * *} \\
(0.003)\end{array}$ & $\begin{array}{l}-0.086^{* * *} \\
(0.004)\end{array}$ & $\begin{array}{l}-0.051^{* * *} \\
(0.003)^{* * *}\end{array}$ & $\begin{array}{l}-0.081^{* * *} \\
(0.007)\end{array}$ & $\begin{array}{l}-0.016^{* * *} \\
(0.005)\end{array}$ \\
\hline High School Only Completed & $\begin{array}{l}-0.149^{* * *} \\
(0.004)^{* * *}\end{array}$ & $\begin{array}{l}-0.183^{* * *} \\
(0.005)^{* * *}\end{array}$ & $\begin{array}{l}-0.126^{* * *} \\
(0.005)^{* * *}\end{array}$ & $\begin{array}{l}-0.172^{* * *} \\
(0.007)_{* * *}\end{array}$ & $\begin{array}{l}-0.074^{* * *} \\
(0.008)^{* * *}\end{array}$ \\
\hline Less Than HS Completed & $\begin{array}{l}-0.175^{* * *} \\
(0.009)\end{array}$ & $\begin{array}{l}-0.201^{* * *} \\
(0.008)\end{array}$ & $\begin{array}{l}-0.140^{* * *} \\
(0.008)^{2 *}\end{array}$ & $\begin{array}{l}-0.207^{* * *} \\
(0.013)\end{array}$ & $\begin{array}{l}-0.064^{* * *} \\
(0.011)\end{array}$ \\
\hline Not Employed & $\begin{array}{l}-0.116^{* * *} \\
(0.004)^{* *}\end{array}$ & $\begin{array}{l}-0.190^{* * *} \\
(0.005)^{* * *}\end{array}$ & $\begin{array}{l}-0.101^{* * *} \\
(0.004)^{* * *}\end{array}$ & $\begin{array}{l}-0.142^{* * *} \\
(0.004)^{* * *}\end{array}$ & $\begin{array}{l}-0.047^{* * *} \\
(0.004)^{* * *}\end{array}$ \\
\hline Not Enrolled in College & $\begin{array}{l}0.083^{* * *} \\
(0.003)\end{array}$ & $\begin{array}{l}0.087^{* * *} \\
(0.004)^{* * *}\end{array}$ & $\begin{array}{l}0.070^{* * *} \\
(0.003)\end{array}$ & $\begin{array}{l}0.084^{* * *} \\
(0.004)\end{array}$ & $\begin{array}{l}0.069^{* * *} \\
(0.005)\end{array}$ \\
\hline Married & $\begin{array}{l}0.399^{* * *} \\
(0.006)\end{array}$ & $\begin{array}{l}0.443^{* * *} \\
(0.003)\end{array}$ & $\begin{array}{l}0.376^{* * *} \\
(0.003)\end{array}$ & $\begin{array}{l}0.418^{* * *} \\
(0.006)\end{array}$ & $\begin{array}{l}0.319^{* * *} \\
(0.005)\end{array}$ \\
\hline Other Marital Status & $\begin{array}{l}0.098^{* * *} \\
(0.002)\end{array}$ & $\begin{array}{l}0.087^{* * *} \\
(0.002)^{* * *}\end{array}$ & $\begin{array}{l}0.079^{* * *} \\
(0.002)^{*}\end{array}$ & $\begin{array}{l}0.099^{* * *} \\
(0.007)\end{array}$ & $\begin{array}{l}0.107^{* * *} \\
(0.003)\end{array}$ \\
\hline Urate $_{\mathrm{t}-1}$ & $\begin{array}{l}-0.141 \\
(0.163)\end{array}$ & $\begin{array}{l}-0.455^{* * *} \\
(0.169)\end{array}$ & $\begin{array}{l}-0.316^{*} \\
(0.186)\end{array}$ & $\begin{array}{l}0.135 \\
(0.341)\end{array}$ & $\begin{array}{l}-0.026 \\
(0.258)\end{array}$ \\
\hline$\Delta$ Urate & $\begin{array}{l}0.023 \\
(0.204)\end{array}$ & $\begin{array}{l}0.003 \\
(0.231)\end{array}$ & $\begin{array}{l}0.050 \\
(0.246)\end{array}$ & $\begin{array}{l}-0.144 \\
(0.504)\end{array}$ & $\begin{array}{l}-0.135 \\
(0.380)\end{array}$ \\
\hline Foreclrate $_{\mathrm{t}-1}$ & $\begin{array}{l}0.006 \\
(0.026)\end{array}$ & $\begin{array}{l}0.020 \\
(0.029)\end{array}$ & $\begin{array}{l}0.027 \\
(0.022)\end{array}$ & $\begin{array}{l}-0.040 \\
(0.052)\end{array}$ & $\begin{array}{l}-0.011 \\
(0.043)\end{array}$ \\
\hline$\Delta$ Foreclrate & $\begin{array}{l}0.023 \\
(0.053)\end{array}$ & $\begin{array}{l}0.082 \\
(0.075)\end{array}$ & $\begin{array}{l}0.021 \\
(0.064)\end{array}$ & $\begin{array}{l}-0.009 \\
(0.128)\end{array}$ & $\begin{array}{l}0.025 \\
(0.089)\end{array}$ \\
\hline Hprice $_{\mathrm{t}-1}$ (in $\left.\$ 100,000 \mathrm{~s}\right)$ & $\begin{array}{l}-0.001 \\
(0.004)\end{array}$ & $\begin{array}{l}-0.005 \\
(0.004)\end{array}$ & $\begin{array}{l}-0.004 \\
(0.005)\end{array}$ & $\begin{array}{l}0.001 \\
(0.008)\end{array}$ & $\begin{array}{l}0.004 \\
(0.007)\end{array}$ \\
\hline$\% \Delta$ Hprice & $\begin{array}{l}0.015 \\
(0.020)\end{array}$ & $\begin{array}{l}0.020 \\
(0.024)\end{array}$ & $\begin{array}{l}-0.008 \\
(0.023)\end{array}$ & $\begin{array}{l}0.018 \\
(0.041)\end{array}$ & $\begin{array}{l}0.027 \\
(0.032)\end{array}$ \\
\hline Rent $_{\mathrm{t}-1}$ (in $\$ 1,000 \mathrm{~s}$ ) & $\begin{array}{l}-0.119^{* * *} \\
(0.043)^{* * *}\end{array}$ & $\begin{array}{l}-0.123^{* * *} \\
(0.040)^{* * *}\end{array}$ & $\begin{array}{l}-0.115^{\text {*** }} \\
(0.033)\end{array}$ & $\begin{array}{l}-0.123 \\
(0.102)\end{array}$ & $\begin{array}{l}-0.129^{*} \\
(0.068)^{* * *}\end{array}$ \\
\hline$\% \Delta$ Rent & $\begin{array}{l}-0.142^{* * *} \\
(0.044)\end{array}$ & $\begin{array}{l}-0.155^{* * *} \\
(0.052)\end{array}$ & $\begin{array}{l}-0.070 \\
(0.045)\end{array}$ & $\begin{array}{l}-0.214^{* * *} \\
(0.082)\end{array}$ & $\begin{array}{l}-0.173^{* * *} \\
(0.067)\end{array}$ \\
\hline Log Likelihood & -585050 & -159128 & -146612 & -140425 & -132258 \\
\hline Observations & 1183226 & 355377 & 330690 & 256703 & 240456 \\
\hline \multicolumn{6}{|c|}{$\begin{array}{l}\text { Notes: Logit models estimated over years } 2006 \text { to } 2011 \text { using data from } 84 \text { of the largest MSAs. All models include } \\
\text { time and MSA fixed effects. Marginal effects are reported. Standard errors (in parentheses) are clustered by MSA. } \\
\text { The race-gender groups are mutually exclusive. } \\
* * * p<0.01, * * p<0.05, * p<0.1\end{array}$} \\
\hline
\end{tabular}

